\title{
Oribatid mite (Acari, Oribatida) richness and diversity in Oak forests of West Azerbaijan Province (Northwestern Iran)
}

\author{
Riqueza y diversidad del ácaro oribátido (Acari, Oribatida) en los bosques de robles \\ de la provincia de Azerbaiyán occidental (noroeste de Irán)
}

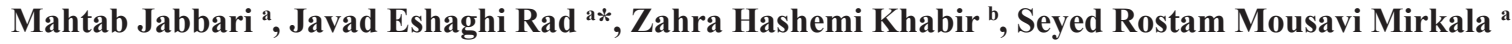 \\ *Corresponding author: a Urmia University, Faculty of Natural Resources, Department of Forestry, Urmia, Iran, \\ tel.: +98 4432770489, j.eshagh@urmia.ac.ir \\ ${ }^{\mathrm{b}}$ Agricultural and Natural Resources Research center, Department of Plant protection, Urmia, Iran.
}

\begin{abstract}
SUMMARY
Up to now, oribatid mite richness and diversity have not been studied in oak forests of Iran. This study aimed at determining the relationships among Oribatid mite composition, richness and diversity as well as ecological factors such as elevation, soil $\mathrm{pH}$ and soil moisture, tree species and stand density in oak forests in northwestern Iran. Thirty samples were randomly arranged at three elevation levels (1,000-1,300 m, 1,300-1,500 m and 1,500-1,650 m). Results indicated that 42 oribatid mite species were recorded in the study area. Nine and six species were exclusively observed in the elevations 1,100-1,300 and 1,300-1,500 m, respectively; while five mite species were commonly recorded in these two elevation categories. The study revealed that oribatid mite composition was affected by elevation gradient; however, the mean differences of species richness and diversity indices were not significant among elevation categories. Moreover, there were no significant correlations either between the densities of most frequent species of oribatid mite species and soil $\mathrm{pH}$ (except for Tectoribates sp.), soil moisture (except for Tectocepheus velatus), elevation, density of Quercus infectoria and density of Quercus libani in study area. Generally, variations in oribatid mite composition were more affected by physiographic factors e.g., altitude than by soil properties and oak species densities, nevertheless no environmental factors influenced oribatid mite richness and diversity in this region.
\end{abstract}

Key words: leaf litter, soil, stand density, Zagros forests.

\section{RESUMEN}

Hasta ahora, la riqueza y diversidad de ácaros oribátidos no se han estudiado en bosques de robles de Irán. Este estudio tuvo como objetivo determinar las relaciones entre la composición, riqueza y diversidad de los ácaros oribátidos, así como factores ecológicos como: elevación, $\mathrm{pH}$ y humedad del suelo, especies de árboles y densidad del rodal en los bosques de robles en el noroeste de Irán. Se dispusieron 30 muestras de forma aleatoria en tres niveles de elevación (1.100-1.300 m, 1.300-1.500 m, 1.500-1.650 m). Se registraron 42 especies de ácaros oribátidos en el área de estudio. Se observaron nueve y seis especies exclusivamente en las elevaciones $1.100-$ 1.300 y 1.300-1.500 m, respectivamente; mientras que cinco especies de ácaros se registraron en ambas categorías de elevación. La composición de ácaros oribátidos se vio afectada por el gradiente de elevación; sin embargo, las diferencias medias de los índices de riqueza y diversidad de especies no fueron significativas entre categorías de elevación. Tampoco hubo correlaciones significativas entre las densidades de las especies más frecuentes de ácaros oribátidos y el pH del suelo (excepto Tectoribates sp.), humedad del suelo (excepto Tectocepheus velatus), elevación, densidad de Quercus infectoria y densidad de Quercus libani. En general, las variaciones en la composición de los ácaros oribátidos se vieron más afectadas por factores fisiográficos, por ejemplo, la altitud que por las propiedades del suelo y la densidad de las especies de robles, pero ningún factor ambiental influyó en la riqueza y diversidad de los ácaros oribátidos en esta región.

Palabras clave: hojarasca, suelo, densidad del rodal, bosques de Zagros.

\section{INTRODUCTION}

The main objective of natural resource management is the biodiversity conservation in natural ecosystems. Species richness, which is the most fundamental level of diversity, is defined as the species count in a given geogra- phic area. Ecosystems with higher diversity include large number of species with equivalent population size. The study of density and structure of soil macro- or microorganisms is important as the segments of the structure of the food web. Oribatid mites are the most abundant and diverse species of soil mesofauna (Schatz and Behan- 
Pelletier 2008). Oribatid mites, in particular, inhabit the soil-litter system and tend to be the dominant arthropod group in highly organic soils of temperate forests (Norton and Behan-Pelletier 2009). They play a significant role in decomposition processes in the soil because they fragment organic matter and influence biomass and species composition of fungi and bacteria (Wallwork 1983, Seastedt 1984, Yoshida and Hijii 2005). Up to now, more than 10,000 species of mites have been described in more than 1,200 genera and 177 families (Schatz et al. 2011, Walter and Proctor 2013). Soil is the most favorable condition for the development of oribatid mites in the forest ecosystem (Manu 2013). The composition of oribatid mite assemblage in soil reflects the stress situation in the soil ecosystem and is useful as a bio-indicator for evaluating soil quality (Ivan 2009). Researchers have already stated that the density of oribatid mites is usually related to climatic factors (Gergócs et al. 2011), the type of forest stands (Murvanidze and Mumladze 2014), vegetation structure (Manu 2013), soil moisture (Corral-Hernández et al. 2016), type of microhabitats (Gergócs et al. 2011) and anthropogenic factors (Ivan 2009). Moreover, Reiff et al. (2016) stated that vegetation could influence the distribution and density of edaphic oribatid mites. In this context it was illustrated that oribatid mite communities were indirectly influenced by litter qualities (Murvanidze and Mumladze 2014, Gergócs et al. 2015) or were not affected by type of leaf litter (Bokhorst et al. 2018, Bluhm et al. 2019). Thus, the relationships between oribatid mite diversity and environmental variables, canopy species composition and stand quantitative characteristics are still complicated and unclear.

According to the latest reports, 380 species belonging to 191 genera from 86 families of oribatid mites have been reported for the Iranian fauna (Akrami 2015). There are few studies concerning the oribatid mites in different habitats in Iran e.g. in pastures (Hashemi-Khabir et al. 2015) and agro-ecosystems (Rahgozar et al. 2019). Similarly, some poronotic oribatid mites (Acari: Oribatida: Poronotic Brachypylina) from Arasbaran forests, North of East Azarbayjan Province, were introduced by Azimi et al. (2018). Zagros forests (ca. 5 million hectares) are the largest forest area in Iran, which is covered with oak trees. The northern parts of these forests are the specific habitat of Quercus infectoria Olivier and Quercus libani Olivier, while the southern parts are solely covered by Quercus brantii Lindley (Eshaghi Rad et al. 2018). It is very valuable to conduct an investigation on oribatid mite species even on regional scale regarding the lack of related data in Zagros forests. Oribatid mite richness and diversity have not been studied in Zagros forests so far and this research was the first case examining oribatid mites in oak forests of Iran. Zagros forests are mainly located on mountainous area and elevation could be a fundamental driver of species composition and species richness and diversity. Indeed, it was illustrated that the patterns of species oc- currence at high altitudes were expected to resemble the species distribution patterns observed at lower altitudes (Hugo-Coetzee and Le Roux 2018). On the other hand, soil $\mathrm{pH}$, soil moisture and stand characteristics could be considered as important factors affecting oribatid mite species composition and diversity. Thus, in this study we hypothesized that a) elevation, soil $\mathrm{pH}$ and soil moisture influenced oribatid mite composition, richness and diversity, b) oribatid mite species responded to stand characteristics such as tree species types and density. The aim of this study is to determine the relationships among oribatid mite composition, richness and diversity as well as some ecological factors such as elevation, soil $\mathrm{pH}$ and soil moisture, tree species and stand density in oak forests in northwestern Iran.

\section{METHODS}

Study area. The research area was located in west Azarbaijan province (Iran), latitude $36^{\circ} 25^{\prime} \mathrm{N}$ and longitude $45^{\circ} 53^{\prime} \mathrm{E}$. The study area is mainly covered by Quercus infectoria Olivier and Quercus libani Olivier situated on north-facing sites with mean slope of $30 \%$ and elevation ranges from 1,100 to $1,650 \mathrm{~m}$ above sea level. Mean annual temperature is $13.5^{\circ} \mathrm{C}$ and mean annual rainfall is $724 \mathrm{~mm}$.

Data collection. For this study three elevation categories $(1,100-1,300 \mathrm{~m}, 1,300-1,500 \mathrm{~m}$ and 1,500-1,650) were determined for allocating the samples. Ten square 400 $\mathrm{m}^{2}(20 \times 20 \mathrm{~m})$ sampling plots were randomly taken in each elevation category (Mumladze et al. 2015). Totally, 30 samples were randomly arranged in the forests of the region. The selection criteria for the samples were as follows:

- - Habitat conditions within stands were homogeneous.

- - No illegal pole and fuel wood cutting within stands.

In each sample, the density and type of tree species in the canopy were recorded. The geographical coordination of the center of each sample was recorded using GPS. Soil samples were taken from the surface $(20 \times 20 \mathrm{~cm})$ up to $20 \mathrm{~cm}$ deep of soil using trowel around the center of each sample plot and afterwards transported to the laboratory at the Urmia Agricultural and Natural Resources Research Center. Soil pH (soil reaction) and soil moisture were determined for the mixed samples in the soil laboratory.

Field sampling and mite extraction. As no significant variation had been observed in the structure of the community and abundance of oribatid mites during the year in oak forests (Gergócs et al. 2011), the oribatid mites were studied by taking 30 mixed litter and soil samples (from surface to a maximum depth of $20 \mathrm{~cm}$ ) in May 2018. Mites 
were extracted by using the Berlese funnel and stored in $75 \%$ ethanol, cleared by Nesbitt's fluid and mounted on microscopic slides using Hoyer's medium. The slides were kept in an oven at $45-50{ }^{\circ} \mathrm{C}$ for $2-3$ weeks and only adult oribatid mites were identified using valid keys (Balogh 1992, Akrami 2015).

Data analysis. Species richness index, Shannon evenness, Shannon diversity index and Simpson diversity index were calculated based on mite species density via software PCORD version 4. Kolmogorov-Smirnov test was applied to check data normality. Tukey test was used to test for significant differences among different elevation categories regarding the species richness, species diversity and evenness indices, and soil properties. The Pearson correlation analysis was applied to analyze relationships between environmental factors (elevation, soil $\mathrm{pH}$, soil moisture, stand density) and the abundance of the most frequent oribatid mites. Further, mite interspecies correlations, mite species density, and tree species types were calculated through this method. SPSS ver. 21.0 for Windows was used for data analyses.

The dominance index (\%) was calculated using the formula $\mathrm{D}=100 \% * \mathrm{n} / \mathrm{N}$, where: $\mathrm{n}=$ number of individuals of one species in all samples; $\mathrm{N}=$ total number of individuals of all species in all samples.

The identified orbatid mites were distributed by dominance as follows: eudominants with $\mathrm{D}>10.0 \%$ (D5), dominants with D of 5.1- $10.0 \%$ (D4), subdominants with $\mathrm{D}$ of $2.1-5.0 \%$ (D3), recedents with D of 1.1-2.0\% (D2), and subrecedents with $\mathrm{D}<1.1 \%$ (D1). The constancy index (\%) was obtained using the formula: $\mathrm{C}=100 \%$ * $\mathrm{pA} / \mathrm{P}$, where: $\mathrm{pA}=$ number of samples with species $\mathrm{A} ; \mathrm{P}$ $=$ total number of samples. Identified mites were classified in four constancy classes: constant species with $\mathrm{C}$ of $75.1-100 \%(\mathrm{C} 4)$, constant species with $\mathrm{C}$ of $50.1-75 \%$ (C3), accessory species with $\mathrm{C}$ of $25.1-50 \%$ (C2), and accidental species with $\mathrm{C}$ of 1-25\% (C1) (Selvin and Vacca 2004).

\section{RESULTS}

Environmental parameters and tree densities. Table 1 reports the mean of studied environmental variables and tree species densities in different elevations categories. It is important to mention that the compositions of all sampling plots were a mixture of $Q$. infectoria and $Q$. libani; nevertheless, the density of each species was different. Soil pH and soil moisture were similar in the different elevation categories.

Oribatid mite distribution along the elevation gradient. A total of 42 oribatid mite species belonging to 29 genera and 24 families were recorded in this study (oak forests in Iran) (table 2). Oribatids mites e.g. Ramusella ( $R a$ musella) sengbuschi tokyoensis (Aoki 1974), Ramusella (Ramusella) sengbuschi s. str. (Hammer 1968), Ramusella (Ramusella) puertomonttensis (Hammer 1962), Ramusella (Insculptoppia) insculpta (Paolo 1908), Ramusella (Rectoppia) mihelcici (Pérez-Ínigo 1965), Lasiobelba (Lasiobelba) decui (Vasiliu et Ivan 1995), Rhinoppia (Rhinoppia) obsoleta (Paoli 1908), Punctoribates punctum (Koch 1839), Punctoribates angulatus (Bayartogtokh, Grobler and Cobanoglu 2000), Tectocepheus velatus (Michael 1880), Sphaerochthonius splendidus (Berlese 1904), Papillacarus aciculatus (Berlese 1905), Plesiodamaeus ornatus (Pérez-Ínígo 1972) were observed in all elevation levels.

Oribatid mites such as Ramusella (Insculptoppiella) varians (Wallwork 1961), Galumna iranensis (Mahunka et Akrami 2001), Berlesezetes aegypticus (Balogh et Mahunka 1981), Atropacarus (Atropacarus) striculus (Koch 1836), Ceratoppia quadridentata (Haller 1882), Epilohmannia cylindrica cylindrica (Berlese 1904) and Suctobelbella (Flagrosuctobelba) elegantula (Hammer 1958) were only found in the elevation 1,100-1,300 m. In addition, Licnodamaeus fissuratus (Balogh et Mahunka 1965), Aleurodamaeus setosus (Berlese 1883), Oribatula (Oribatula) pallida (Banks 1906) and Passalozetes africanus (Grand-

Table 1. The mean \pm standard error of studied environmental variables and tree species densities in the study area.

Media \pm error estándar de las variables ambientales estudiadas y las densidades de especies arbóreas en el área de estudio.

\begin{tabular}{lcccc}
\hline \multirow{2}{*}{ Characteristics } & \multicolumn{3}{c}{ Elevation categories $(\mathrm{m})$} & Total \\
\cline { 2 - 4 } & $1,100-1,300$ & $1,300-1,500$ & $1,500-1,650$ & $7.5 \pm 0.26$ \\
\hline $\mathrm{pH}$ & $7.5 \pm 0.25$ & $7.4 \pm 0.21$ & $7.6 \pm 0.30$ & $12.6 \pm 3.2$ \\
Moisture (\%) & $12.4 \pm 3.3$ & $11.3 \pm 1.5$ & $13.9 \pm 3.1$ & $1,398.3 \pm 51.9$ \\
Elevation (m) & $1,200.2 \pm 70.3$ & $1,410.3 \pm 59.2$ & $1,584.4 \pm 24.1$ & $29.2 \pm 7.7$ \\
Q. infectoria density & $42.1 \pm 11.3$ & $28.1 \pm 5.4$ & $17.3 \pm 6.5$ & $18.8 \pm 5.3$ \\
Q. libani density & $10.7 \pm 4.4$ & $24.4 \pm 7.5$ & $21.3 \pm 4.1$ & $47.9 \pm 14.4$ \\
Total density & $52.8 \pm 16.2$ & $52.5 \pm 15.1$ & $38.6 \pm 12.1$ & \\
\hline
\end{tabular}


jean 1932) were collected in the elevation 1300-1500 m. Similarly, Lasiobelba (Lasiobelba) kuehnelti (Csiszár 1961), Oribatula (Zygoribatula) connexa ucrainica (Iordansky 1990), Scheloribates fimbriatus (Thor 1930) and Indoribates )Haplozetes) fusifer (Berlese, 1908) were observed in both $1100-1300 \mathrm{~m}$ and $1300-1500 \mathrm{~m}$ categories.

Half of the collected species (21 species) had dominance lower than $1 \%$ (table 2). Punctoribates punctum had the highest dominance $(\mathrm{D}=11.9 \%)$. In the study area, 41 mite species had constancy index lower than $50 \%$. Tectocepheus velatus had the highest constancy $(\mathrm{C}=53 \%$ ) (table 2$)$.

Species richness and diversity indices. Table 3 indicates the species richness, evenness, Shannon diversity and Simpson diversity indices of mites recorded in oak stands located in various elevation categories in the study area. There were no significant differences in the mean of species diversity indices among the elevation categories $(P$ value $<0.05$ based on Tukey test results).

Mite species abundance-environment relationship. The correlations between the abundance of most frequent species of oribatid species and the studied environmental factors (elevation, soil $\mathrm{pH}$, soil moisture, oak species density, and total stand density) in the study area are indicated in table 4. The abundance of Tectocepheus velatus is significantly correlated with soil moisture. There is also a significant correlation between Tectoribates sp. and soil pH; however, other mite species do not respond to soil $\mathrm{pH}$ or soil moisture. In addition, there is no significant correlation between the abundance of most frequent species of oribatid species and elevation, density of $Q$. infectoria and density of $Q$. libani in the study area.

Mite interspecies correlation. Table 5 indicates the correlation among different species of oribatid mites recorded in the sampling plots in the study area. There appears to be a significant positive correlation between the Pilogalumna sp. and $R .(R$.) sengbuschi tokyoensis, Sphaerochthonius splendidus and Tectoribates sp. species as well as between Tectocepheus velatus and Punctoribates angulatus. Likewise, there is a significant negative correlation between the Tectoribates $\mathrm{sp}$. and $R$.(R.) sengbuschi tokyoensis and $R$. $(R$.) puertomonttensis. Other pair correlations among mite species were not significant in the study area.

\section{DISCUSSION}

A total of 42 oribatid mite species were recorded in this study (oak forests in Iran). Species including Ramusella (Insculptoppiella) varians, Ramusella (Rectoppia) mihelcici, Lasiobelba (Lasiobelba) decui, Lasiobelba (Lasiobelba) kuehnelti, Scheloribates laevigatus (C.L. Koch, 1835), Epilohmannia cylindrica cylindrica, Ceratoppia quadridentata, Suctobelbella (Flagrosuctobelba) elegantula and Papillacarus aciculatus (Berlese, 1905) were new records for oak forests of this region, which were previously reported in different habitats in Iran e.g. in pastures (HashemiKhabir et al. 2015) and Arasbaran temperate forests (Azimi et al. 2018). Likewise, Ramusella (Insculptoppia) insculpta, Oppiella (Oppiella) nova nova (Oudemans, 1902) and Rhinoppia (Rhinoppia) obsoleta were reported in oak forests in Turkey (Toluk and Akin 2017) as well as Scheloribates laevigatus and Oppiella (Oppiella) nova nova in Romania (Ivan 2009).

Approximately $67 \%$ of the collected species ( 28 from 42 species) had dominance under $2 \%$ and most mite species (41 species) in the study area belonged to accessory and accidental species classes (table 2). According to literature, the high numbers of recedent, subrecedent, accessory and accidental species indicate an unfavorable impact of environmental conditions on stability of the studied populations (Manu 2013).

Nine and six species were exclusively observed in the elevations $1,100-1,300 \mathrm{~m}$ and $1,300-1,500 \mathrm{~m}$ respectively. In addition, five mite species were recorded in the elevations $1,100-1,300 \mathrm{~m}, 1,300-1,500 \mathrm{~m}$, although absent above $1,500 \mathrm{~m}$. Thus, oribatid mite composition was affected by elevation gradient. In agreement with this result, Mumladze et al. (2015) illustrated that the oribatid mite composition was influenced by elevation gradient. This could be related to lower temperatures and generally harsher environment in high elevations (Hugo-Coetzee and Le Roux 2018) or a combination of increasing biotic harshness with decreasing availability of food resources as the driving factors for changing species composition along gradients (Fischer et al. 2014).

The absence of a significant difference in mite species richness and diversity indices among elevation categories of the study area may be due to the higher resistance of mites to changes in environmental variables (Reiff et al. 2016 ) as well as minor variations of soil $\mathrm{pH}$ and soil moisture in the study area. Nevertheless, many studies indicated that mite species richness and diversity declined with increasing elevation (Hugo-Coetzee and Le Roux 2018, Bokhorst et al. 2018). These contrasting responses may be related to variation in vegetation or soil type, precipitation, elevation range and temperature range (Hodkinson 2005).

Our results also indicated no significant correlation between the abundance of most frequent oribatid species and the density of oak species in study area. Reportedly, a dense stand makes a great amount of leaf litter on the forest floor that can serve as protection for soil biota (Reiff et al. 2016). However, the stands in the Zagros forests in the region were dominated by oak species which did not make dense stands. Meanwhile, oak litter is favorable for all types of oribatid communities (Gergócs et al. 2015). In line with this result, Hugo-Coetzee and Le Roux (2018) illustrated that plant characteristics did not affect mite and springtail species patterns. Further, Bokhorst et al. (2018) proved that mite abundance was unaffected by vegetation type. In addition, Bluhm et al. (2019) stated that tree spe- 
Table 2. Family, scientific name, frequency, abundance, dominance and constancy indices of Oribatid mite in study area. Familia, nombre científico, frecuencia, abundancia, dominancia e índices de constancia del ácaro oribátide en el área de estudio.

\begin{tabular}{|c|c|c|c|c|c|c|c|c|}
\hline \multirow[t]{2}{*}{ Family } & \multirow[t]{2}{*}{ Species } & \multicolumn{3}{|c|}{$\begin{array}{c}\text { Frequency in elevation } \\
\text { categories }(\mathrm{m})\end{array}$} & \multirow[t]{2}{*}{$\mathrm{D} \%$} & \multirow[t]{2}{*}{$\mathrm{C} \%$} & \multirow[t]{2}{*}{$\mathrm{n}$} & \multirow{2}{*}{$\begin{array}{c}\% \\
\text { abundance }\end{array}$} \\
\hline & & $<1,300$ & $1,300-1,500$ & $>1,500$ & & & & \\
\hline Sphaerochthoniidae & Sphaerochthonius splendidus & 2 & 3 & 3 & 4.4 & 27 & 38 & 4.42 \\
\hline Steganacaridae & Atropacarus (Atropacarus) striculus & 1 & 0 & 0 & 0.1 & 3 & 1 & 0.11 \\
\hline Phthiracaridae & Phthiracarus lentulus & 1 & 0 & 1 & 0.4 & 7 & 4 & 0.46 \\
\hline Lohmanniidae & Papillacarus aciculatus & 2 & 3 & 2 & 2.2 & 23 & 19 & 2.2 \\
\hline Epilohmanniidae & Epilohmannia cylindrica cylindrica & 1 & 0 & 0 & 0.6 & 3 & 6 & 0.69 \\
\hline Hermanniellidae & Hermanniella sp. & 1 & 0 & 0 & 0.1 & 3 & 1 & 0.11 \\
\hline Gymnodamaeidae & Plesiodamaeus ornatus & 1 & 3 & 1 & 1.6 & 17 & 14 & 1.62 \\
\hline Aleurodamaeidae & Aleurodamaeus setosus & 0 & 2 & 0 & 0.2 & 7 & 2 & 0.23 \\
\hline Licnodamaeidae & Licnodamaeus fissuratus & 0 & 1 & 0 & 0.1 & 3 & 1 & 0.11 \\
\hline Damaeolidae & Belba sp. & 1 & 1 & 2 & 1.8 & 13 & 16 & 1.86 \\
\hline \multirow{2}{*}{ Xenillidae } & Xenillus (Xenillus) setosus & 0 & 1 & 0 & 0.1 & 3 & 1 & 0.11 \\
\hline & Xenillus (Xenillus) sp.nr. singularis & 0 & 1 & 1 & 0.5 & 7 & 5 & 0.58 \\
\hline Metrioppidae & Ceratoppia quadridentata & 3 & 0 & 0 & 0.3 & 10 & 3 & 0.34 \\
\hline \multirow{2}{*}{ Tectocephidae } & Tectocepheus minor & 0 & 1 & 0 & 0.1 & 3 & 1 & 0.11 \\
\hline & Tectocepheus velatus & 6 & 6 & 4 & 7.4 & 53 & 64 & 7 \\
\hline \multirow{10}{*}{ Oppiidae } & Ramusella (Ramusella) sengbuschi tokyoensis & 3 & 3 & 4 & 2.9 & 33 & 25 & 2.91 \\
\hline & Ramusella (Ramusella) sengbuschi s.str. & 7 & 2 & 4 & 0.1 & 43 & 86 & 10.01 \\
\hline & Ramusella (Ramusella) puertomonttensis & 3 & 2 & 2 & 1.8 & 23 & 16 & 1 \\
\hline & Ramusella (Insculptoppia) insculpta & 2 & 1 & 1 & 0.8 & 13 & 7 & 0.81 \\
\hline & Ramusella (Insculptoppiella) varians & 1 & 0 & 0 & 0.1 & 3 & 1 & 0.11 \\
\hline & Ramusella (Rectoppia) mihelcici & 1 & 1 & 1 & 0.9 & 10 & 8 & 0.93 \\
\hline & Lasiobelba (Lasiobelba) decui & 3 & 1 & 1 & 3.6 & 17 & 34 & 3.95 \\
\hline & Lasiobelba (Lasiobelba) kuehnelti & 2 & 2 & 0 & 5.3 & 13 & 46 & 5.35 \\
\hline & Oppiella (Oppiella) nova nova & 2 & 0 & 2 & 1.2 & 13 & 11 & 1.28 \\
\hline & Rhinoppia (Rhinoppia) obsoleta & 1 & 1 & 1 & 0.5 & 10 & 5 & 0.58 \\
\hline Epimerellidae & Epimerella sp. & 4 & 0 & 0 & 5.8 & 13 & 50 & 5.82 \\
\hline Suctobelbidae & Suctobelbella (Flagrosuctobelba) elegantula & 1 & 0 & 0 & 0.1 & 3 & 1 & 0.11 \\
\hline Microzetidae & Berlesezetes aegypticus & 1 & 0 & 0 & 0.1 & 3 & 1 & 0.11 \\
\hline Passalozetidae & Passalozetes africanus & 0 & 3 & 0 & 0.6 & 10 & 6 & 0.6 \\
\hline \multirow{4}{*}{ Oribatulidae } & Oribatula (Oribatula) pallida & 0 & 1 & 0 & 0.1 & 3 & 1 & 0.11 \\
\hline & Oribatula (Oribatula) tibialis allifera & 1 & 0 & 1 & 1.3 & 7 & 12 & 1.39 \\
\hline & Oribatula (Zygoribatula) connexa ucrainica & 1 & 1 & 0 & 2.2 & 7 & 19 & 2 \\
\hline & Oribatula (Zygoribatula)debilitranslamellata & 1 & 0 & 1 & 2.5 & 7 & 22 & 2.56 \\
\hline \multirow{2}{*}{ Scheloribatidae } & Scheloribates fimbriatus & 1 & 2 & 0 & 1 & 10 & 9 & 1.04 \\
\hline & Scheloribates laevigatus & 1 & 0 & 1 & 0.2 & 7 & 2 & 0.23 \\
\hline Haplozetes & Indoribates) Haplozetes (fusifer & 2 & 2 & 0 & 3.7 & 13 & 32 & 3.72 \\
\hline \multirow{2}{*}{ Punctoribatidae } & Punctoribates punctum & 5 & 4 & 1 & 11.9 & 33 & 103 & 11 \\
\hline & Punctoribates angulatus & 3 & 3 & 6 & 5.1 & 40 & 44 & 5 \\
\hline \multirow{2}{*}{ Achipteriidae } & Tectoribates sp. & 4 & 2 & 0 & 6.6 & 20 & 57 & 6.63 \\
\hline & Achipteria sp. & 1 & 1 & 2 & 1.5 & 13 & 13 & 1.51 \\
\hline \multirow{2}{*}{ Galumnidae } & Pilogalumna sp. & 5 & 1 & 4 & 5.3 & 33 & 71 & 8 \\
\hline & Galumna iranensis & 1 & 0 & 0 & 0.1 & 3 & 1 & 0.11 \\
\hline
\end{tabular}

D: dominance index, C: constancy index, n: number of individuals. 
Table 3. Species richness and diversity indices of Oribatid mites in the elevation categories.

Índices de riqueza y diversidad de especies de ácaros oribátidos en las categorías de elevación.

\begin{tabular}{ccccc}
\hline \multirow{2}{*}{ Parameter } & \multicolumn{3}{c}{ Elevation categories $(\mathrm{m})$} \\
\cline { 2 - 4 } & $1,100-1,300$ & $1,300-1,500$ & $1,500-1,650$ & Total \\
\hline Species richness & $8.44 \pm 1.95$ & $6.22 \pm 1.37$ & $5.11 \pm 0.96$ & $6.60 \pm 3.50$ \\
Evenness & $0.69 \pm 0.10$ & $0.62 \pm 0.10$ & $0.90 \pm 0.30$ & $0.74 \pm 0.27$ \\
Shannon index & $1.43 \pm 0.27$ & $1.08 \pm 0.24$ & $1.29 \pm 0.13$ & $1.27 \pm 0.67$ \\
Simpson Index & $0.62 \pm 0.10$ & $0.48 \pm 0.09$ & $0.67 \pm 0.03$ & $0.59 \pm 0.26$ \\
\hline
\end{tabular}

Table 4. Pearson correlation between most frequent Oribatid mite species and environmental factors (elevation, soil pH, soil moisture, stand density) in the study area.

Correlación de Pearson entre las especies de ácaros oribátidos más frecuentes y factores ambientales (elevación, pH del suelo, humedad del suelo, densidad del rodal) en el área de estudio.

\begin{tabular}{lcccccc}
\hline & $\mathrm{pH}$ & $\begin{array}{c}\text { Soil } \\
\text { moisture }\end{array}$ & Elevation & $\begin{array}{c}\text { Q. infecoria } \\
\text { density }\end{array}$ & $\begin{array}{c}\text { Q. libani } \\
\text { density }\end{array}$ & $\begin{array}{c}\text { Total } \\
\text { density }\end{array}$ \\
\hline Punctoribates punctum & 0.26 & 0.36 & 0.36 & -0.22 & 0.37 & -0.64 \\
Tectocepheus velatus & 0.03 & $0.55^{*}$ & 0.12 & 0.19 & -0.11 & 0.38 \\
Punctoribates angulatus & 0.16 & -0.03 & -0.01 & -0.01 & 0.01 & 0.24 \\
Ramusella (R.) puertomonttensis & -0.21 & -0.09 & -0.59 & 0.73 & -0.18 & 0.72 \\
Sphaerochthonius splendidus & -0.25 & -0.40 & 0.04 & -0.14 & -0.05 & -0.32 \\
Papillacarus aciculatus & -0.56 & -0.17 & -0.30 & 0.19 & 0.66 & -0.30 \\
Ramusella (R.) sengbuschi tokyoensis & -0.33 & -0.59 & -0.63 & 0.38 & -0.55 & 0.55 \\
Ramusella (R.) sengbuschi s.str. & 0.41 & -0.06 & -0.31 & -0.01 & 0.07 & 0.28 \\
Pilogalumna sp. & 0.29 & 0.58 & 0.22 & -0.23 & 0.16 & 0.18 \\
Tectoribates sp. & $0.85^{* *}$ & 0.16 & 0.19 & -0.36 & 0.01 & 0.15 \\
\hline
\end{tabular}

*Significant differences $P<0.05$. **Significant differences $P<0.01$

cies (Fagus sylvatica L., Acer pseudoplatanus L., Fraxinus excelsior L. and Tilia cordata Mill.) with different leaf litter quality did not affect species richness or community structure of oribatid mites. However, contrasting results were obtained in other studies regarding mite-vegetation relationships based on the type of vegetation. Rieff et al. (2016) found a superior number of mites in soil samples from the area under eucalyptus compared to the native grassland area. Besides, Murvanidze and Mumladze (2014) observed that different types of litter (beech versus hornbeam) had a significant impact on the overall number of species and abundance of oribatid mites.

Furthermore, we observed a weak correlation between the abundance of different oribatid mites in the study area (table 5). It was stated that oribatid mites coexisted in the same habitat since mite species where found to have di- fferent diets (Schneider et al. 2004) and oribatid species were known to be general feeders (Maraun et al. 2003). Alternatively, it might be due to partitioning of the feeding resource in a competitive way (Murvanidze and Mumladze 2014).

\section{CONCLUSIONS}

Overall, oribatid mite species composition in Zagros oak forests was different at different elevations. However, no significant correlation was observed among most of frequent mite densities and the species diversity indices and elevation, soil $\mathrm{pH}$ and soil moisture. Generally, variations in oribatid mite composition were more affected by physiographic factors e.g. altitude than by soil properties and oak species densities. In addition, no environmental 
Table 5. Pearson correlation among most frequent Oribatid mite species in the study area.

Correlación de Pearson entre las especies de ácaros oribátidos más frecuentes en el área de estudio.

\begin{tabular}{|c|c|c|c|c|c|c|c|c|c|c|}
\hline &  & 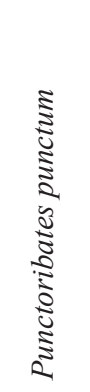 & 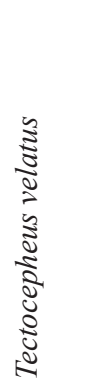 & 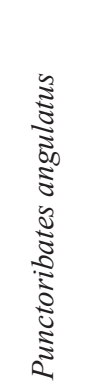 & 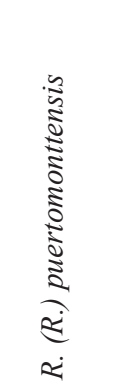 & 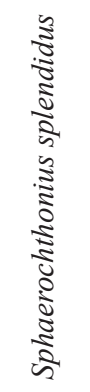 & 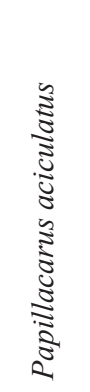 &  & 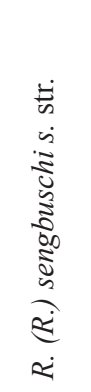 & 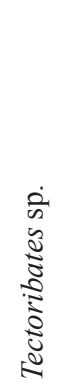 \\
\hline Pilogalumna sp. & 1.00 & & & & & & & & & \\
\hline Punctoribates punctum & -0.29 & 1.00 & & & & & & & & \\
\hline Tectocepheus velatus & 0.13 & -0.40 & 1.00 & & & & & & & \\
\hline Punctoribates angulatus & 0.22 & -0.02 & $0.76^{*}$ & 1.00 & & & & & & \\
\hline R.(R.)puertomonttensis & -0.32 & -0.46 & 0.41 & $\mathrm{a}$ & 1.00 & & & & & \\
\hline Sphaerochthonius splendidus & $0.99^{* *}$ & -0.06 & -0.11 & 0.35 & -0.50 & 1.00 & & & & \\
\hline Papillacarus aciculatus & -0.40 & a & -0.41 & 0.82 & a & 0.50 & 1.00 & & & \\
\hline$R$. (R.) sengbuschi tokyoensis & $0.99^{* *}$ & -0.47 & -0.10 & -0.11 & a & 0.08 & -0.94 & 1.00 & & \\
\hline R.(R.) sengbuschi s. str. & 0.07 & -0.39 & -0.16 & 0.31 & 0.33 & 0.02 & -0.19 & 0.26 & 1.00 & \\
\hline Tectoribates sp. & $0.99^{* *}$ & -0.40 & -0.16 & -0.88 & $-0.99 * *$ & -0.53 & -0.84 & $-0.99 * *$ & -0.24 & 1.00 \\
\hline
\end{tabular}

*Significant differences $P<0.05$. **Significant differences $P<0.01$. a: one of species is absent.

factors impacted oribatid mite richness or diversity in this region and Oribatid mite species did not respond to stand characteristics such as tree species types and density.

\section{ACKNOWLEDGMENTS}

We would like to thank Miss Ayeshe Esmaeili for assistance in the field work. The presented research has been financially supported by the vice chancellor for research and technology of Urmia University.

\section{REFERENCES}

Akrami MA, A. Saboori. 2012. Acari of Iran, Vol. 2, Oribatid mites. Tehran, Iran. Tehran University Press. 261p.

Akrami MA. 2015. An annotated checklist of oribatid mites (Acari: Oribatida) of Iran. Zootaxa 3963(4): 451-501. DOI: http://dx.doi.org/10.11646/zootaxa.3963.4.1

Azimi N, D Shirdel, P Lotfollahi, A Khalil Ariya. 2018. Introduction of Some Poronotic Oribatid Mites (Acari: Oribatida: Poronotic Brachypylina) from Arasbaran Forests, North of East Azarbaijan Province. Applied Research in Plant Pathology 7(3): 117-123.

Balogh J, P Balogh. 1992a. The oribatid mites genera of the world. Vol. 1. Budapest, Hungary. The Hungarian National Museum Press. 263 p.
Balogh J, P Balogh. 1992a. The oribatid mites genera of the world. Vol. 2. Budapest, Hungary. The Hungarian National Museum Press. 375 p.

Bluhm C, O Butenschoen, M Maraun, S Scheu.2019. Effects of root and leaf litter identity and diversity on oribatid mite abundance, species richness and community composition. PLos One 14(7): 1-16. DOI: https://doi.org/10.1371/journal.pone.0219166

Bokhorst S, GF Veen, M Sundqvist, JR De Long, P Kardol, DA Wardle. 2018. Contrasting responses of springtails and mites to elevation and vegetation type in the sub-Arctic. Pedobiologia 67: 57-64. DOI: https://doi.org/10.1016/j. pedobi.2018.02.004

Corral-Hernández E, I Balanzategui, JC Iturrondobeitia. 2016. Effect of progressive drying of pedunculate oak (Quercus robur L.) and holm oak (Quercus rotundifolia Lam.) forest soils on the composition of the oribatid mite community (Acari: Oribatida) in laboratory conditions. International Journal of Acarology 42(7): 358-365. DOI: https://doi.org/ $\underline{10.1080 / 01647954.2016 .1194470}$

Eshaghi Rad J, G Valadi, O Salehzadeh, H Maroofi. 2018. Effects of anthropogenic disturbance on plant composition, plant diversity and soil properties in oak forests, Iran. Journal of Forest Science 64(8): 358-370. DOI: https://doi. org/10.17221/13/2018-JFS

Fischer BM, E Meyer, M Maraun, 2014. Positive correlation of trophic level and proportion of sexual taxa of oribatid 
mites (Acari: Oribatida) in alpine soil systems. Experimental and Applied Acarology 76: 112-123. DOI: https://doi. org/10.1007/s10493-014-9801-3

Gergócs V, Á Garamvölgyi, R Homoródi, L Hufnagel. 2011. Seasonal change of oribatid mite communities (Acari, Oribatida) in three different types of microhabitats. Applied Ecology and Environmental Research 9(2): 181-195. DOI: http:// dx.doi.org/10.15666/aeer/0902 181195

Gergócs V, G Rétháti, L Hufnagel. 2015. Litter quality indirectly influences community composition, reproductive mode and trophic structure of oribatid mite communities: a microcosm experiment. Experimental and Applied Acarology 67(3): 35-56. DOI: https://doi.org/10.1007/s10493-015-9959-3

Hashemi-Khabir Z, K Haddad Irani-Nejad, M Moghaddam, M Khanjani. 2015. Community structure of oribatid mites (Acari: Oribatida) in rangelands of West Azerbaijan Province, Iran. International Journal of Acarology 41(4): 344-355. DOI: https://doi.org/10.1080/01647954.2015.10 $\underline{33458}$

Hodkinson ID. 2005. Terrestrial insects along elevation gradients: species and community responses to altitude. Biological Review 80: 489-513. DOI: https://doi.org/10.1017/ $\underline{\mathrm{S} 1464793105006767}$

Hugo-Coetzee EA, PC Le Roux. 2018. Distribution of microarthropods across altitude and aspect in the sub-Antarctic: climate change implications for an isolated oceanic island. Acarologia 58: 43-60. DOI: http://dx.doi.org/10.24349/ acarologia/20184278

Ivan O. 2009. Structure and dynamics of the oribatid mite communities (Acari,Oribatida) in some Quercus forests, in relation with the treatments used in the control of defoliating insects. Annals of Forest Research 52: 5-10.

Manu M. 2013. Diversity of soil mites (Acari: Mesostigmata: Gamasina) in various deciduous forest ecosystems of Muntenia region (southern Romania). Biological Letters 50(1): 3-16. DOI: http://dx.doi.org/10.1016/S11645563(03)00006-2

Maraun M, H Martens, S Migge, A Theenhaus, S Scheu. 2003. Adding to the enigma of soil animal diversity: fungal feeders and saprophagous soil invertebrates prefer similar food substrates. European Journal of Soil Biology 39: 85-95. https://doi.org/10.2478/biolet-2013-0001

Mumladze L, M Murvanidze, M Maraun, M Salakaia. 2015. Oribatid mite communities along an elevational gradient in Sairme gorge (Caucasus). Experimental and Applied Acarology 66(1): 41-51. https://doi.org/10.1007/s10493-0159893-4

Murvanidze M, L Mumladze. 2014. Article Oribatid mite (Acari: Oribatida) diversity in different forest stands of Borjom-
Kharagauli National Park (Georgia). Persian Journal of Acarology 3(4): 257-276. DOI: http://dx.doi.org/10.22073/ pja.v3i4.10169

Ndri JK, SD Zon, JE Tondoh, J Lagerlöf. 2017. Changes in mite richness and diversity along a gradient of land-use intensity from mid-west Ivory Coast. Tropical Ecology 58(3): 497-506.

Rahgozar M, K Iraninejad, MN Zargaran, A Saboori. 2019. Biodiversity and species richness of oribatid mites (Acari: Oribatida) in orchards of East Azerbaijan province, Iran. Persian Journal of Acarology 8(2): 147-159. DOI: http:// dx.doi.org/10.22073/pja.v8i2.43052

Rieff GG, T Natal-da-Luz, J Paulo Sousa, MO Wallau, M Hahn, EL de Sá1.2016.Collembolans and mites communities as a tool for assessing soil quality: effect of eucalyptus plantations on soil mesofauna biodiversity. Current Science 110(4): 713-719. DOI: https://doi.org/10.18520/cs/v110/i4/713-719

Schatz H, V Behan-Pelletier. 2008. Global diversity of oribatids (Oribatida: Acari: Arachnida). Hydrobiologia 595: 323 328. DOI: https://doi.org/10.1007/s10750-007-9027-z

Schatz H, NM Behan-Pelletier, BM Oconnor, RA Norton. 2011. Suborder Oribatida van der Hammen, 1968. In Zhang ZQ ed. Animal biodiversity: An outline of higher-level classification and survey of taxonomic richness. Zootaxa 3148: 141148. DOI: http://dx.doi.org/10.11646/zootaxa.3148.1.26

Schneider K, C Renker, S Scheu, M Maraun. 2004. Feeding biology of oribatid mites: a mini review. Phytophaga 14: 247-256.

Seastedt TR. 1984. The role of microarthropods in decomposition and mineralization processes. Annual Review of Entomology 29: 25-46.

Selvin S, A Vacca. 2004. Biostatistics. How it works.London, England. 408 p.

Subías LS. 2004. Listado sistematico, sinonimico y biogeografico de los acaros oribatidos (Acariformes, Oribatida) del Mundo (1758-2002). Graellsia 60: 3-305. DOI: https:// doi.org/10.3989/graellsia.2004.v60.iExtra.218

Toluk A, AT Akin. 2017. Oribatid mite fauna (Acari) of Çat Forest, Sivas Province, Turkey. Turkish Journal of Entomology 41(3): 293-307. DOI: http://dx.doi.org/10.16970/entoted.322866

Wallwork JA. 1983. Oribatids in forest ecosystems. Annual Review of Entomology 28:109-130.

Walter DE, HC Proctor. 2013. Mites: Ecology, Evolution, and Behavior. 2nd edition. Dordrecht, Netherlands. Springer. $470 \mathrm{p}$.

Yoshida T, N Hijii. 2005. The composition and abundance of microarthropod communities on arboreal litter in the canopy of Cryptomeria japonica trees. Journal of Forest Research 10:35-42. DOI: $\underline{\text { https://doi.org/10.1007/s10310-004-0098-7 }}$ 